\title{
Reference Ranges for Hematological Values in Umbilical Cord Blood in Pokhara, Nepal
}

\author{
Basnet $\mathrm{S}^{1}$, Singh SK$^{2}$, Sathian $\mathrm{B}^{3}$, Mishra $\mathrm{R}^{4}$
}

${ }^{1}$ Dr. Sahisnuta Basnet, MBBS, MD. Assistant Professor, Department of Paediatrics, ${ }^{2} \mathrm{Dr}$. Sandip Kumar Singh, MBBS, MD Resident, Department of Paediatrics, ${ }^{3}$ Dr. Brijesh Sathian, MBBS, MD. Assistant Professor, Department of Community Medicine, ${ }^{4} \mathrm{Dr}$. Rajnish Mishra, MBBS, MD Resident Department of Paediatrics. All from the Manipal College of Medical Sciences, Fulbari, Pokhara, Nepal.

\section{Address for correspondence:}

Dr. Sahisnuta Basnet, Assistant Professor, Department of Paediatrics

Manipal College of Medical Sciences,

Fulbari, Pokhara,

Nepal

Tel: +9779802813777

E-mail: sahisb@hotmail.com

Acknowledgements: None

Funding: Nil

Conflict of Interest: None

Permission from IRB: Yes

Ethical dilemmas faced during study: No

\section{How to cite}

Basnet S, Singh SK, Sathian B, Mishra R. Reference Ranges for Hematological Values in Umbilical Cord Blood in Pokhara, Nepal. J Nepal Paediatr Soc 2016;36(2):160-164.

doi: http://dx.doi.org/10.3126/jnps.v36i2.15605

This work is licensed under a Creative Commons Attribution 3.0 License.

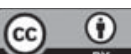

\begin{abstract}
Introduction: Reference hematological values in newborns are informative in evaluation of newborns to determine state of health or disease. For a given population, reference values may differ in accordance with various factors such as age, sex, race, diet, drug intake, altitude, socio-economic status and also the method employed for determination of the values. The aim of this study was to establish reference ranges of complete blood count using umbilical cord blood of normal, healthy, full term neonates born in Manipal Teaching Hospital (MTH), Pokhara, Nepal.Material and Method: The study was conducted in 210 full term, healthy newborns delivered in MTH between Jan 2014 to Feb 2015. Cord blood was collected and a complete blood count was obtained using an automated hematology analyzer.Result: Mean hemoglobin was $15.24 \pm$ $1.96 \mathrm{gm} / \mathrm{dl}$ and mean red blood cell count was $4.30 \pm 0.63$ (range $3.05-6.36$ ) $\times 10^{12} / \mathrm{L}$. Mean white blood cell count was $14.93 \pm 4.44$ (range $6.10 \pm 31.7$ ) $\times 10^{\%} / \mathrm{L}$ and platelet count was $226.88 \pm 61.28$ (range $105 \pm 392$ ) X 10\%/L. There was no significant difference found in hemoglobin, red cell, white cell and platelet counts between males and females in this study. Conclusion: The values obtained from our study provide ranges for some hematological values in healthy newborns of Pokhara Nepal. However, the hematological reference values for Nepalese cord blood needs to be confirmed by larger numbers of samples from different centers of Nepal.
\end{abstract}

Key words: complete blood count parameters, umbilical cord blood, newborn

\section{Introduction}

$\mathrm{T}$ he Complete Blood Count CBC parameters varies with age, race, sex, diet, drugs, analytical methods and other various factors and therefore, the concept of an universal "normal" value of complete blood count has changed to reference values for a given population ${ }^{1,2,3}$. This means that it is important to carry out studies to establish standard reference values for the local population ${ }^{3}$.Complete blood count $(C B C)$ is one of the most commonly carried out investigation when assessing the health status of an individual; not only is it a simple investigation to carry out, it is also relatively fast, cost effective and a reliable indicator of the health of a person ${ }^{1}$. 
Measuring the hemoglobin $(\mathrm{Hb})$ is important for diagnosis of anemia and polycythemia; red cell indices provide useful information in elucidating causes of anemias. White blood cell (WBC) and platelets are responsible for providing information regarding sepsis and hemostatic status ${ }^{1}$.

These CBC parameters of newborns are different than that of adults and therefore should be interpreted in their contexts. We, in developing countries generally rely on reference ranges obtained from European and American populations and it becomes important to compare whether our local values match those of other studies. As per the authors' knowledge, there has been no study until date regarding the CBC parameters of newborns in Nepal. So, this study was carried out to establish mean values for CBC in cord blood in our setting and also to compare our values with those obtained from other similar studies.

\section{Materials and methods}

A total of 210 neonatal cord blood samples were collected to be included in this cross sectional observational study. The study was conducted from January 2014 to February 2015. Consent was also obtained from the parents in all the cases, and only those who agreed to partake in the study were included.

All the babies were born in Manipal Teaching Hospital (MTH), Pokhara,Nepal either by normal vaginal delivery or elective Caesarian section. The newborns were selected on the basis of the following criteria: birth at full term (37-42 weeks), normal birth weight (2500 - 4000 grams), uneventful antenatal period and absence of congenital anomalies. Babies of mothers who had chronic diseases or intrapartum complications such as fever, diabetes mellitus, pregnancy induced hypertension, and anemia were excluded from the study.
After the umbilical cord was clamped, $2 \mathrm{ml}$ of blood was taken from the umbilical cord and transferred into a vial containing ethylenediaminetetraacetic acid (EDTA). The vial was then immediately transported to the pathology laboratory for determination of cord blood hemoglobin, hematocrit, red blood cell count, $\mathrm{MCV}, \mathrm{MCH}, \mathrm{MCHC}$, total white blood cell count with differentials, and platelet. The CBC was done with an automated hematology analyzer (Lab Life H3D Premier).

Data was analyzed using SAS University Edition. Descriptive analysis was performed for the calculation of range, mean, and standard deviation. Z-test for mean was performed manually in Table 3 to establish the statistically significant difference between means of our study variables compared to the mean of other study variables. Other study variables mean, standard deviation and sample size was available in the peer reviewed journals and we have cited them wherever it has been quoted.

Approval was obtained from the institutional ethical committee of MTH.

\section{Results}

A total of 210 healthy, term newborns (one hundred [47.6\%] males and 110 [52.4\%] females) were enrolled in this cross sectional study; Complete blood count parameters (hemoglobin, total WBC including differential counts, RBC counts, platelets, $\mathrm{MCV}, \mathrm{MCH}, \mathrm{MCHC}$ ) are summarized in Table 1.Twenty-five neonates in our study had $\mathrm{Hb}$ levels below $13 \mathrm{gm} / \mathrm{dl}$ and three had $\mathrm{Hb}$ above $20 \mathrm{gm} / \mathrm{dl}$.

Table 2 depicts the above mentioned parameters in umbilical cord blood for males and females. As the result summarizes, there were no significant differences between the parameters of the two genders.

Table 1: Complete blood parameters in neonatal cord blood

\begin{tabular}{lcc}
\hline Parameters & Range & Mean \pm SD \\
\hline WBC (X 10\%/L) & $6.10-31.70$ & $14.93 \pm 4.44$ \\
\hline Neutrophils (\%) & $23-86$ & $63.09 \pm 11.62$ \\
\hline Lymphocytes (\%) & $14-77$ & $35.02 \pm 11.54$ \\
\hline Eosinophils (\%) & $0-7$ & $1.24 \pm 1.55$ \\
\hline Monocytes(\%) & $0-4$ & $0.48 \pm 0.74$ \\
\hline Basophils (\%) & 0 & 0 \\
\hline Hemoglobin (gm/dl) & $11.10-20.80$ & $15.24 \pm 1.96$ \\
\hline RBC (X 1012/L) & $3.05-6.36$ & $4.30 \pm 0.63$ \\
\hline MCV (fl) & $84.5-118.60$ & $101.22 \pm 6.01$ \\
\hline MCH (pg) & $27.20-39.20$ & $33.91 \pm 2.27$ \\
\hline MCHC (gm/dl) & $28.70-36.90$ & $33.27 \pm 1.58$ \\
\hline Platelets (X 10\%) & $105-392$ & $226.88 \pm 61.28$ \\
\hline
\end{tabular}

Abbreviations: WBC, white blood cells; RBC, red blood cells; MCV, mean corpuscular volume; $\mathrm{MCH}$, mean corpuscular hemoglobin; $\mathrm{MCHC}$, mean corpuscular hemoglobin concentration; SD, standard deviation 
Table 2: Gender distribution of complete blood count parameters

\begin{tabular}{lcc}
\hline Parameter & $\begin{array}{c}\text { Mean } \pm \text { SD } \\
\text { (Male) } \\
\text { n } \mathbf{1 0 0 ~ ( 4 7 . 6 \% )}\end{array}$ & $\begin{array}{c}\text { Mean } \pm \text { SD } \\
\text { (Female) }\end{array}$ \\
$\mathbf{n = 1 1 0 ~ ( 5 2 . 4 \% ) ~}$
\end{tabular}

Abbreviations:WBC, white blood cells; RBC, red blood cells; MCV, mean corpuscular volume; $\mathrm{MCH}$, mean corpuscular hemoglobin; $\mathrm{MCHC}$, mean corpuscular hemoglobin concentration; SD, standard deviation

Table 3: Comparison of overall mean values \pm SD of complete blood count parameters in umbilical cord blood between our study and various other studies.

\begin{tabular}{|c|c|c|c|c|c|c|c|}
\hline $\begin{array}{l}\text { Parameter } \\
\text { Mean } \pm S D\end{array}$ & Our study & $\begin{array}{l}\text { Babil (Iraq) } \\
\text { study }^{6}\end{array}$ & $\begin{array}{c}\text { Karachi } \\
\text { (Pakistan) } \\
\text { study }^{2} \\
\end{array}$ & $\begin{array}{c}\text { Malawian } \\
\text { (East Africa) } \\
\text { study }^{7}\end{array}$ & $\begin{array}{c}\text { Mashhad } \\
\text { (Iran) study }{ }^{5}\end{array}$ & $\begin{array}{c}\text { Abidjan } \\
\text { (Ivory Coast) } \\
\text { study }^{8}\end{array}$ & $\begin{array}{l}\text { Al-nahrain } \\
\text { (Iraq) study }{ }^{9}\end{array}$ \\
\hline $\begin{array}{l}\text { Hemoglobin } \\
(\mathrm{gm} / \mathrm{dl})\end{array}$ & $15.24 \pm 1.96$ & $13.76 \pm 1.46^{\star *}$ & $14.99 \pm 1.47+$ & $16 \pm 1.7^{* *}$ & $15.9 \pm 1.96^{* *}$ & $15 \pm 1.7+$ & $15.32 \pm 0.80+$ \\
\hline $\operatorname{RBC}\left(X 10^{12} / L\right)$ & $4.30 \pm 0.63$ & $4 \pm 0.47^{* *}$ & $4.29 \pm 0.44+$ & $4.52 \pm 0.57^{\star *}$ & $4.45 \pm 1.96+$ & $4.370 \pm 0.51+$ & $4.35 \pm 0.47+$ \\
\hline MCV (fl) & $101.22 \pm 6.01$ & $111.56 \pm 6.09^{* *}$ & $105.81 \pm 6.24^{* \star}$ & $112.6 \pm 8.9^{* *}$ & $108.7 \pm 1.96^{\star *}$ & $100 \pm 6.2+$ & $104.5 \pm 2.91^{* *}$ \\
\hline $\mathrm{MCH}(\mathrm{pg})$ & $33.91 \pm 2.27$ & $34.41 \pm 2.36^{*}$ & $34.96 \pm 2.11^{* *}$ & $31.9 \pm 5.5^{\star *}$ & $35.8 \pm 1.96^{\star *}$ & $34.5 \pm 2.4$ * & $35.39 \pm 1.67^{* *}$ \\
\hline $\mathrm{MCHC}(\mathrm{gm} / \mathrm{dl})$ & $33.27 \pm 1.58$ & $30.93 \pm 1.90^{* *}$ & $32.47 \pm 2.12^{* *}$ & $33.5 \pm 2.8+$ & $33 \pm 1.96^{*}$ & $34.2 \pm 1.0^{* *}$ & $33.74 \pm 0.96^{\star *}$ \\
\hline $\begin{array}{l}\text { Total WBC (X } \\
\left.10^{9} / \mathrm{L}\right)\end{array}$ & $14.93 \pm 4.44$ & $10.12 \pm 2.8^{* *}$ & $13.61 \pm 4.23^{\star *}$ & $12.3 \pm 4.8^{* *}$ & $11.62 \pm 1.96^{* *}$ & $13.7 \pm 5.4^{*}$ & $15.1 \pm 3.17+$ \\
\hline $\begin{array}{l}\text { Lymphocytes } \\
(\% \%)\end{array}$ & $35.20 \pm 11.54$ & $39.8 \pm 10.17^{\star \star}$ & $39.89 \pm 12.24^{\star *}$ & 37.39 & $42 \pm 1.96^{\star *}$ & $36.5 \pm 12.3+$ & 30.9 \\
\hline $\begin{array}{l}\text { Neutrophils } \\
\text { (\%) }\end{array}$ & $63.09 \pm 11.62$ & $51 \pm 11.24^{* *}$ & $50.13 \pm 12.44$ & 62.60 & $48 \pm 1.96$ & $54.4 \pm 15.4$ & 61.5 \\
\hline Monocytes (\%) & $0.48 \pm 0.74$ & $7.8 \pm 2.77^{\star \star}$ & $6.56 \pm 2.86^{\star *}$ & 2.27 & $7 \pm 1.96^{\star *}$ & $9.0 \pm 4.6^{* *}$ & 2.25 \\
\hline Basophils (\%) & 0 & $0.10 \pm 0.97+$ & $1.13 \pm 0.73$ & 0.16 & $0 \pm 1.96$ & $0.4 \pm 0.7$ & 0 \\
\hline $\begin{array}{l}\text { Eosinophils } \\
(\%)\end{array}$ & $1.24 \pm 1.55$ & $1.22 \pm 0.97+$ & $3.31 \pm 2.17^{\star *}$ & 1.38 & $3 \pm 1.96^{* *}$ & $1.8 \pm 1.8^{* *}$ & 1.52 \\
\hline $\begin{array}{l}\text { Platelet count } \\
\left(\mathrm{X} 10^{9} / \mathrm{L}\right)\end{array}$ & $226.88 \pm 61.28$ & $267.63 \pm 60.62^{\star *}$ & $256.25 \pm 76.54^{* *}$ & $259.9 \pm 72.55^{\star *}$ & $257 \pm 1.96^{* *}$ & $161 \pm 45^{\star *}$ & $\begin{array}{c}221.8 \pm 27.26 \\
+\end{array}$ \\
\hline
\end{tabular}

Abbreviations: WBC, white blood cells; RBC, red blood cells; MCV, mean corpuscular volume; $\mathrm{MCH}$, mean corpuscular hemoglobin; $\mathrm{MCHC}$, mean corpuscular hemoglobin concentration; SD, standard deviation

Note: *significant; **highly significant; +not significant 


\section{Discussion}

In Table 3, we have compared our CBC findings with other similar studies done in Iraq,Pakistan, Malawi, Iran, Abidjan, 2,5,6,7,8,9. Comparisons have been made between our study and these studies and various other studies.

Hemoglobin: Reference values for cord blood hemoglobin in our study were $15.24 \pm 1.96 \mathrm{gm} / \mathrm{dl}$. These values were comparable to studies done in Buenos Aires $(15.5 \pm 1.1 \mathrm{gm} / \mathrm{dl})$, Sindh, Pakistan $(15.4 \pm 1.9 \mathrm{gm} /$ $\mathrm{dl})$, and Karachi, Pakistan (14.99 $\pm 1.47 \mathrm{gm} / \mathrm{dl})^{2,3,10}$. Similar studies done in Greece, Nigeria and Taiwan showed reference values which were lower than the ones seen in our study $(8.8 \pm 2.9 ; 13.29 \pm 1.5$; and $11.2 \pm 1.5 \mathrm{gm} / \mathrm{dl}$ respectively ${ }^{1,11,12}$. In contrast, a study from Scandinavia had reported much higher hemoglobin values $(19.3 \pm 2.2 \mathrm{gm} / \mathrm{dl})$ than seen in our study ${ }^{13}$.

The differences in hemoglobin values in these studies could be attributed to different time intervals between birth and cord clamping, use of haemantics by the mother during pregnancy and also ethnic/racial differences. As higher levels were seen in countries with higher altitudes, this could also be another contributing factor in higher levels seen in Nepal and Pakistan.

Red Blood Cell Count:The red blood cell (RBC) count in our study was found to be similar to the values obtained from Karachi, Mashhad, Abidjan and Al-rahrain 2,5,8,9. Higher figures were seen in Malawian neonates and lower ranges were cited by Al-Marzoki et al in Babil, Iraq ${ }^{6,7}$.

Red Cell Indices:Mean corpuscular volume (MCV) in our study $(101.22 \pm 6.01 \mathrm{fl})$ was similar to the values seen in an African study $(100 \pm 6.2 \mathrm{fl})$ and in Chandigarg, India (102.4 $\pm 7.1 \mathrm{fl})^{8,14}$ but lower than other comparable studies done in Babil, Iraq (111.56 $\pm 6.09 f 1)$, Malawi (112.6 $\pm 8.9 \mathrm{fl})$, Scandanavia $(119.9 .4 \pm 9.4 \mathrm{fl})$ and Iran $(108.7 \pm 1.96 \mathrm{fl})^{5,6,7,13}$.

Mean corpuscular hemoglobin $(\mathrm{MCH})$ was found to be higher in the Al-nahrain study in comparison to ours ${ }^{14}$. However, the values seen in Malawi was significantly lower?

The mean corpuscular hemoglobin concentration $(\mathrm{MCHC})$ in our study $(33.27 \pm 1.58 \mathrm{gm} / \mathrm{dl})$ was similar to the findings in the Malawian neonates $(33.5 \pm 2.8 \mathrm{gm} / \mathrm{dl})^{7}$ while we saw that the findings seen in Iraqi neonates in a study done by Al-Mudallal et al showed higher $\mathrm{MCHC}$ values $(35.39 \pm 1.67 \mathrm{gm} / \mathrm{dl})^{9}$. However, lower figures were seen in the same country done in a study by AlMarzoki et al in Babil, Iraq $(30.93 \pm 1.90 \mathrm{gm} / \mathrm{dl})^{6}$.

The values of the red cell indices may have been varied in different studies due to factors such as maternal stress, differences in the socio- economic conditions, stature of the mothers and geographical distributions $\mathbf{s}^{1,2,6,14,15}$.

White Blood Cells: The total white blood cell count was seen to be $14.93 \pm 4.44 \times 10^{9} / \mathrm{L}$ in the current study. This value was comparable to the counts seen in a study by Al-Mudallal et al $\left(15.1 \pm 3.17 \times 10^{9} / \mathrm{L}\right)^{9}$. Much lower figures were seen in studies done in Babil, Iraq $\left(10.12 \pm 2.8 \times 10^{\%} / L\right)$ and Nigeria $\left(9.88 \pm 2.93 \times 10^{\%} / L\right)$ and in Greece $\left(7.2 \pm 3.4 \times 10^{9} / \mathrm{L}\right)^{6,11,16}$.

Regarding the differential counts, neutrophils were higher in our study in comparison to studies done in Karachi $(50.13 \pm 12.44 \%)$ and Chandigarh, India $(52.5 \pm 16.0 \%)^{2,14}$. Lymphocytes in the current study agree with those seen in Abidjan $(36.5 \pm 12.3 \%)^{8}$. However, our findings were lower than in the studies done in Mashhad, Iran (42 $\pm 1.96 \%)$, Karachi, Pakistan $(39.89 \pm 12.24 \%)$ and Babil, Iraq $(39.8 \pm 10.17 \%)^{2,5,6}$.

Significantly higher percentages of monocytes were seen in other studies in comparison with ours; this is demonstrated in studies done in Abidjan, Iran, and Babil, Iraq ${ }^{5,6,7}$.Eosinophil in our study was similar to those found in Babil, Iraq, but higher counts were seen in neonates in Karachi, Mashad, Iran, and Adidjan²,5,8.

We did not find any basophils in the umbilical cord blood of the 210 studied samples. This finding was in concordance with that of neonates in Al-nahrain?

Method of counting could account for some differences in counts in our center and elsewhere. In the Nigerian study, manual methods were utilized as automated hematological analyzer was not available in their center ${ }^{16}$. Higher levels of leucocytic counts in our study could also be related to the mode of delivery. Studies have shown that newborns born by vaginal route have higher levels of WBC count ${ }^{2,14,17}$. It is possible that larger number of the mothers underwent vaginal delivery in our study though we did not take this factor into account in our study. Further studies needs to be done regarding differences in WBC counts between those newborns born by vaginal vs. caesarean section in order to further potentiate this theory.

Platelets: Platelet count in the present study was in agreement with the counts cited by a Nigerian study ${ }^{1}$. 
However, platelets were noted to be higher in studies in Sindh, Pakistan and in Sudanese neonates ${ }^{3,15}$. On the other hand, Greek $\left(160 \pm 59 \times 10^{9} / \mathrm{L}\right)$ and Northern Indian (199.2 $\left.\pm 56.55 \times 10^{\%} / \mathrm{L}\right)$ neonates were observed to have platelet values which were lower than seen in our Nepalese newborns ${ }^{11,14}$.

The differences in platelet count in different studies has been largely linked to contamination with Wharton's jelly, mechanical trauma while cutting the umbilical cord and the procedure done in order to estimate the count i.e whether manual or automated machines were used ${ }^{2}$.

\section{References}

1. Adewumi A, Titilope A A, Akinsegun AA, et al. Cord blood full blood count parameters in Lagos, Nigeria. Pan AfrMed J 2014;17:192. doi:10.11604/ pamj.2014.17.192.3680

2. Qaiser DH, Sandila MP, Ahmed ST, et al. Haematological reference values for full term, healthy, newborns of Karachi, Pakistan. J Pak Med Assoc 2009;59(9):618.

3. Pasha W, Ali W, Ahmed N, et al.,. Reference haematological values for full term healthy newborns from rural Sindh, Pakistan. J Ayub Med Coll Abbottabad 2015;27(2):375-77.

4. Ozyure E, Cetintas S, Ceylan T et al. Complete blood count parameters for healthy, small for gestational age full term newborns. Clin Lab Hematol 2006;28(2):97-106.

5. Keramati MR, Mohammadzadeh A, Farhat AS, et al.. Determination of Hematologic Reference Values of Neonates in Mashhad-Iran. Int J Hematol Oncol 2011;21:103-4.

6. Al-Marzoki JM, Al-Maaroof ZW, Kadhum $\mathrm{AH}$. Determination of reference ranges for full blood count parameters in neonatal cord plasma in Hilla, Babil, Iraq J Blood Med 2012;3:113.

7. Mukiibi JM, Mtimavalye LA, Broadhead R, et al. Some haematological parameters in Malawian neonates. East Afr Med J 1995;72(1):10-4.

8. Reinhardt MC, Marti HR. Haematological data of African newborns and their mothers in Abidjan. Helv Paediatr Acta (Suppl) 1978;41:85-99.

\section{Conclusion}

Thus, our study provides the first ever reference range for our own population Reference values for hematological parameter which are used in Nepal is based on observations on other populations. This study shows that there are similarities as well as differences in complete blood count parameters in comparison to other studies. It is suggested that the hematological reference values for Nepali newborns should be confirmed using larger number of data from different regions of Nepal.

9. Salem Al-Mudallal S, Abd Al-Moeen Al-Habbobi M. Evaluation of the effect of mode of delivery on hematological paramters of healthy full-term newborns.Iraqi J Med Sci 2010;8:30-32.

10. Noguera NI, Detarsio G, Perez SM, et al. Hematologic study of newborn umbilical cord blood. Medicina (Buenos Aires) 1999;59:446-48.

11. Katsares V, Paparidis Z, Nikolaidou et al. Reference Ranges for Umbilical Cord Blood Hematological Values. Lab Med 2009;40(7):437-39.

12. Chang $\mathrm{YH}$, Yang $\mathrm{SH}$, Wang TF, et al. Complete blood count reference values of cord blood in Taiwan and the influence of gender and delivery route on them. Pediatr Neonatol 2011 ;52(3):155-60.

13. Matoth $\mathrm{Y}$, Zaizor R, Varsano I. Postnatal changes in some red cell parameters. ActaPediatr Scand 1971;60(3):317-23.

14. Marwaha RK, Narang A, Thusu K, et al. Routine hematological values in term newborns. Indian Pediatr 1992;29(9):1095-99.

15. Elgari MM, Waggiallah HA. Cord Blood Hematological Profile of Sudanese Neonates at Birth in Khartoum State.NJIRM 2014;5(5):22-25.

16. Dapper DV, Didia BC. Haemorheological parameters of umbilical cord blood of Nigerian newborns: Correlations with maternal parameters. West Afr JMed 2006;25(3):226-30.

17. Al-Zubaidy W, Mansoor SS, Musa RJ. Hematological parameters in healthy neonates delivered by vaginal route and cesarean section. Iraqi J Med Sci 2000;51(3.1):40-44 